\title{
Pengujian Tetrazolium dan Respirasi Benih Koro Pedang (Canavalia ensiformis)
}

\section{Tetrazolium and Seed Respiration Tests of The Jack Bean Seed (anavalia ensiformis)}

\author{
Silmy Fadillah Rahmayani, Tatiek Kartika Suharsi*, Memen Surahman
}

Departemen Agronomi dan Hortikultura, Fakultas Pertanian, Institut Pertanian Bogor (Bogor Agricultural University), Jl. Meranti, Kampus IPB Darmaga, Bogor 16680, Indonesia Telp. \& Faks. 62-251-8629353 e-mail agronipb@indo.net.id

*Penulis Korespondensi: t.suharsi@yahoo.co.id

Disetujui 7 Januari 2015/ Publish online 15 januari 2015

\begin{abstract}
Recently, jack bean has been developed as the substitution commodity of soybean because of its high protein content. The aim of this research was to test the viability of the jack bean seed with tetrazolium testing and seed respiration testing. This research used three different lots of jack bean seed : seed lot A (harvested March 2014 in Bojong Bogor, kept in storage with room temperature), seed lot B (harvested November 2013 in Ciherang Bogor, kept in storage in air conditioned room), and seed lot C (harvested September 2012 in Leuwikopo Bogor, kept in storage in air conditioned room). This research consisted of two experiments. Experiment 1 was tetrazolium test. Experiment 2 was seed respiration test. Each experiment used Randomized Complete Design with physical rapid aging as the factor, which consisted of 0, $8,12,16,20$ hours. The result of experiment 1 showed that the tetrazolium coloration topography patterns of the jack bean seed not usable yet to evaluate fisiology quality of the jack bean seed. The result of experiment 2 showed that the method of seed respiration test with cosmotector not usable yet to evaluate fisiology quality of the jack bean seed.
\end{abstract}

Keywords: seed respiration test, seed viability, seed vigor, tetrazolium test

\begin{abstract}
ABSTRAK
Koro pedang saat ini dikembangkan sebagai komoditas substitusi kedelai karena kandungan proteinnya yang cukup tinggi. Tujuan penelitian ini adalah untuk menguji viabilitas benih koro pedang dengan pengujian tetrazolium dan pengujian respirasi benih. Penelitian ini menggunakan tiga lot benih koro pedang yang berbeda yaitu lot benih A (dipanen bulan Maret 2014 di Bojong Bogor, disimpan dalam ruang kamar), lot benih B (dipanen bulan November 2013 di Ciherang Bogor, disimpan dalam ruang ber-AC), dan lot benih C (dipanen bulan September 2012 di Leuwikopo Bogor, disimpan dalam ruang ber-AC). Penelitian ini terdiri dari dua percobaan. Percobaan 1 ialah pengujian tetrazolium. Percobaan 2 ialah penguijian respirasi benih. Masing-masing percobaan menggunakan rancangan acak lengkap dengan pengusangan cepat secara fisik sebagai faktornya, yang terdiri atas $0,8,12,16$, dan 20 jam. Hasil percobaan 1 menunjukkan bahwa pola topografi pewarnaan tetrazolium benih koro pedang belum bisa digunakan untuk mengevaluasi mutu fisiologis benih koro pedang. Hasil percobaan 2 menunjukkan bahwa metode pengujian respirasi benih dengan cosmotector belum bisa digunakan untuk mengevaluasi mutu fisiologis benih koro pedang.
\end{abstract}

Kata kunci: pengujian respirasi benih, pengujian tetrazolium, viabilitas benih, vigor benih 


\section{PENDAHULUAN}

Koro pedang (Canavalia ensiformis) saat ini mulai diproduksi dan dikembangkan sebagai komoditas substitusi kedelai karena kandungan proteinnya yang cukup tinggi yaitu $29.8 \%$ (Doss et al. 2011). Puslitbangtan (2007) menambahkan bahwa produksi benih koro pedang dapat mencapai 4.5 ton biji kering ha ${ }^{-1}$.

Salah satu penentu keberhasilan dalam kegiatan produksi benih koro pedang ialah penggunaan benih bermutu fisiologis tinggi. Mutu fisiologis benih berkaitan dengan tingkat viabilitas atau daya hidup benih. Informasi mengenai mutu fisiologis benih diperoleh dari pengujian benih. Indikasi dari pengujian benih ada dua jenis, yaitu indikasi langsung dan indikasi tidak langsung. Pengujian benih indikasi langsung ialah dengan mengamati gejala pertumbuhan, sedangkan pengujian benih indikasi tidak langsung tidak menghasilkan kecambah (Sadjad 1993).

Pengujian benih indikasi tidak langsung di antaranya ialah pengujian tetrazolium dan pengujian respirasi benih. Menurut ISTA (2014), pengujian tetrazolium merupakan pengujian secara biokimiawi yang digunakan untuk mendapatkan nilai viabilitas benih secara cepat menggunakan larutan 2,3,5-trifenil tetrazolium klorida/bromida. Larutan tetrazolium diimbibisi ke dalam benih lalu berikatan dengan hidrogen yang dilepaskan oleh enzim dehidrogenase pada proses reduksi dalam sel-sel yang hidup sehingga menghasilkan endapan trifenil formazan berwarna merah yang mengindikasikan benih hidup sedangkan pada benih mati tidak terjadi proses reduksi sehingga benih mati menjadi tidak berwarna.

Pengujian respirasi benih merupakan pengujian yang dapat mendeteksi laju respirasi benih dengan mengukur kadar gas $\mathrm{CO}_{2}$ yang dihasilkan dalam proses respirasi benih. Pengujian respirasi benih telah dilakukan pada beberapa benih pangan menggunakan cosmotector tipe XP314 yang berfungsi sebagai alat pengukur kadar $\mathrm{CO}_{2}$. Pengujian respirasi benih jagung (Zea Mays) oleh Nurfarida (2011) menghasilkan laju respirasi benih yang berkorelasi nyata dengan parameter viabilitas dan vigor benih. Hasil pengujian respirasi benih kedelai (Glycine max) oleh Permatasari (2011) menunjukkan bahwa semakin tinggi laju respirasi benih maka semakin tinggi pula viabilitas dan vigor benihnya. Menurut Baharizki (2012), pengujian respirasi benih kacang tanah (Arachis hypogaea) juga menunjukkan bahwa semakin tinggi laju respirasi benih maka semakin tinggi pula viabilitas dan vigor benihnya.

Waktu yang diperlukan untuk pengujian tetrazolium ataupun pengujian respirasi benih pada benih koro pedang kurang dari dua hari, sedangkan pengujian benih koro pedang dengan indikasi langsung membutuhkan waktu tujuh hari. Oleh karena itu, pengujian tetrazolium dan pengujian respirasi benih dapat memberikan informasi mutu fisiologis benih koro pedang dengan waktu yang lebih cepat. Informasi mutu fisiologis benih yang berasal dari pengujian tetrazolium atau pengujian respirasi benih sebaiknya dikonfirmasikan kembali dengan pengujian viabilitas benih dengan indikasi langsung sehingga ketepatan informasinya terjamin.

\section{METODE PENELITIAN}

Penelitian ini dilaksanakan pada bulan Juli - September 2014. Penelitian ini dilaksanakan di Laboratorium Benih dan Laboratorium Pascapanen AGH IPB, serta Greenhouse Kebun Percobaan Leuwikopo Darmaga Bogor. Bahan yang digunakan dalam penelitian ini ialah tiga lot benih koro pedang yang berbeda waktu dan tempat panen serta kondisi ruang penyimpanannya, yaitu lot benih A (dipanen bulan Maret 2014 di Bojong Bogor, disimpan dengan karung kain dalam ruang kamar suhu 25$30{ }^{\circ} \mathrm{C}$ dan $\mathrm{RH} 60-75 \%$ ), lot benih B (dipanen bulan November 2013 di Ciherang Bogor, disimpan dengan kantong plastik dalam ruang berAC suhu $20-23{ }^{\circ} \mathrm{C}$ dan $\mathrm{RH} 30-33 \%$ ), dan lot benih C (dipanen bulan September 2012 di Leuwikopo Bogor, disimpan dengan karung plastik dalam ruang ber-AC suhu $20-23{ }^{\circ} \mathrm{C}$ dan RH 30 - 33\%). Bahan lain yang digunakan dalam penelitian ini ialah 2,3,5 Trifenil Tetrazoliumklorida, aquades, pasir, plastik polypropylene, kertas alumunium, selotip, dan label. Alat yang digunakan dalam penelitian ini ialah waterbath tipe NTT-1200, cosmotector tipe XP-314, oven, toples inkubasi, timbangan digital, box plastik, gelas kaca, desikator, cawan, gunting pangkas, pinset, dan sudip.

Lot benih koro pedang didevigorasi dengan pengusangan cepat secara fisik menggunakan waterbath tipe NTT-1200 bersuhu $40{ }^{0} \mathrm{C}$ dan $\mathrm{RH} \approx 100 \%$ dengan lima taraf penderaan $(0,8,12,16$, dan 20 jam $)$ dan tiga ulangan sehingga terdapat 15 satuan percobaan untuk masing-masing lot benih. Satu satuan percobaan menggunakan 75 butir benih yang dibagi menjadi tiga bagian, yaitu bagian pertama untuk pengujian tetrazolium sebanyak 25 butir 
benih, bagian kedua untuk pengujian respirasi benih sebanyak 25 butir benih, dan bagian ketiga untuk pengujian langsung sebanyak 25 butir benih.

Penelitian ini terdiri dari dua percobaan. Percobaan pertama ialah pengujian tetrazolium benih koro pedang yang diawali dengan pembuatan pola topografi pewarnaan tetrazolium benih koro pedang setelah diperoleh sub lot benih hasil pengusangan secara fisik. Masing-masing lima sub lot benih A, B, dan C sebanyak 10 butir direndam dalam aquades selama 12 jam. Kulit benih koro pedang dikupas dan keping kotiledon dibuka tapi tidak sampai terpisah. Benih koro pedang direndam dengan larutan tetrazolium $1 \%$, $0.5 \%$, dan $0.1 \%$ dalam gelas kaca kedap cahaya yang telah dibungkus dengan kertas alumunium, lalu dimasukkan ke dalam oven bersuhu $30{ }^{\circ} \mathrm{C}$ selama $18 \mathrm{jam}$. Larutan tetrazolium dengan konsentrasi $1 \%, \quad 0.5 \%$, dan $0.1 \%$ tidak menunjukkan adanya perbedaan dari segi intensitas pewarnaan sehingga konsentrasi $0.1 \%$ dipilih untuk digunakan pada tahap selanjutnya dalam pengujian tetrazolium benih koro pedang karena lebih ekonomis. Pengamatan pola yang terbentuk dilakukan dengan mengacu pada pola topografi pewarnaan tetrazolium benih kedelai dan penilaiannya terhadap bagian-bagian esensial benih yang terwarnai dan tidak terwarnai. Hasilnya diperoleh sembilan pola topografi pewarnaan tetrazolium benih koro pedang yang dikelompokkan menjadi benih hidup, benih mati, kecambah normal kuat, kecambah normal, dan kecambah abnormal.

Pengujian tetrazolium benih koro pedang dilakukan setelah pola topografi pewarnaan selesai dibuat. Benih koro pedang sebanyak 25 butir per satu satuan percobaan direndam dalam aquades selama 12 jam. Kulit benih koro pedang dikupas dan keping kotiledon dibuka tapi tidak sampai terpisah. Benih koro pedang direndam dengan larutan tetrazolium $0.1 \%$ dalam gelas kaca kedap cahaya yang telah dibungkus dengan kertas alumunium, lalu dimasukkan ke dalam oven bersuhu $30{ }^{0} \mathrm{C}$ selama $18 \mathrm{jam}$. Pengamatan dilakukan dengan mencocokkan topografi pewarnaan pada benih koro pedang yang telah direndam dalam larutan tetrazolium dengan pola topografi pewarnaan tetrazolium benih koro pedang yang telah dibuat penguji, sehingga didapat nilai benih hidup, kecambah normal kuat, dan kecambah normal. Selanjutnya, nilai benih hidup, kecambah normal kuat, dan kecambah normal dibandingkan dengan nilai PTM, DB, dan
KST hasil pengujian benih koro pedang dengan indikasi langsung.

Percobaan kedua ialah pengujian respirasi benih koro pedang yang diawali dengan perendaman 25 butir benih per satu satuan percobaan dalam aquades selama $12 \mathrm{jam}$. Benih dimasukkan ke dalam toples inkubasi, ditutup rapat, direkatkan dengan isolasi, dan disimpan selama 24 jam dalam suhu ruang kamar. Konsentrasi $\mathrm{CO}_{2}$ dalam toples inkubasi diukur menggunakan cosmotector tipe XP-314, lalu hasilnya dimasukkan kedalam rumus laju respirasi benih. Nilai laju respirasi benih koro pedang dibandingkan dengan nilai PTM, DB, IV, $\mathrm{K}_{\mathrm{ST}}$, dan $\mathrm{K}_{\mathrm{CT}}$.

Pengujian viabilitas dan vigor benih koro pedang dengan indikasi langsung juga dilakukan sebagai pembanding pengujian tetrazolium dan pengujian respirasi benih. Pengujian langsung dilakukan dalam greenhouse dengan $27-29{ }^{\circ} \mathrm{C}$ dan RH 60-70\% menggunakan media pasir dengan metode penanaman in sand selama 7 hari dengan hitungan pertama pada hari ke-5 dan hitungan kedua pada hari ke-7. Setiap satu satuan percobaan ditanam 25 butir benih (Febriyanti 2013). Parameter pengamatan terdiri dari PTM, $\mathrm{DB}, \mathrm{IV}, \mathrm{K}_{\mathrm{ST}}$, dan $\mathrm{K}_{\mathrm{CT}}$.

Masing-masing percobaan menggunakan rancangan acak lengkap (RAL) dengan satu faktor perlakuan yaitu pengusangan cepat secara fisik. Pengolahan data dianalisis dengan sidik ragam (Uji F) dengan taraf 5\% pada aplikasi SAS dan jika terdapat pengaruh yang nyata maka diuji lanjut dengan menggunakan DMRT (Duncan Multiple Range Test). Data hasil pengujian tetrazolium dan pengujian respirasi dibandingkan dengan data hasil pengujian langsung dengan cara dianalisis korelasi pearson dan regresi linier sederhana.

\section{HASIL DAN PEMBAHASAN}

\section{Kondisi Awal Lot Benih Koro Pedang}

Kadar air dan viabilitas awal lot benih koro pedang ditunjukkan pada Tabel 1. Lot benih A memiliki kadar air diatas $14 \%$, sedangkan lot benih $\mathrm{B}$ dan lot benih $\mathrm{C}$ memiliki kadar air dibawah 12\%. Menurut (Distan 2013), kadar air yang aman untuk benih tanaman pangan (ortodoks) ialah maksimal 12\%. Masing-masing lot benih memiliki viabilitas dengan tolok ukur DB yang masih cukup tinggi yaitu diatas $80 \%$, sesuai dengan standar DB untuk benih tanaman pangan yaitu diatas 80\% (Distan 2013). 
Tabel 1. Kadar air dan viabilitas awal empat lot benih koro pedang

\begin{tabular}{lllllll}
\hline \multirow{2}{*}{ Lot Benih } & \multicolumn{5}{c}{ Tolok Ukur } \\
\cline { 2 - 7 } & KA $(\%)$ & PTM $(\%)$ & DB $(\%)$ & IV $(\%)$ & $\mathrm{K}_{\mathrm{ST}}(\%)$ & $\mathrm{K}_{\mathrm{CT}}\left(\%\right.$ etmal $\left.^{-1}\right)$ \\
\hline A & 14.99 & 96.00 & 90.67 & 36.00 & 61.33 & 15.71 \\
B & 11.73 & 97.33 & 88.00 & 49.33 & 65.33 & 16.06 \\
C & 9.41 & 98.67 & 97.33 & 60.00 & 76.00 & 17.71 \\
\hline
\end{tabular}

KA : kadar air; PTM : potensi tumbuh maksimum; DB : daya berkecambah; IV : indeks vigor; $\mathrm{K}_{\mathrm{ST}}$ : keserempakan tumbuh; $\mathrm{K}_{\mathrm{CT}}$ : kecepatan tumbuh

\section{Percobaan 1 : Pengujian Tetrazolium Benih Koro Pedang}

Percobaan 1 diawali dengan pembuatan pola topografi pewarnaan tetrazolium benih koro pedang yang menghasilkan sembilan pola topografi pewarnaan tetrazolium benih koro pedang. Pola 1 ialah benih berwarna merah terang secara merata. Pola 2 ialah benih berwarna merah terang dengan sedikit warna merah tua pada kotiledon. Pola 3 ialah benih berwarna merah agak tua dan masih ada bagian yang berwarna merah terang. Pola 4 ialah benih berwarna merah terang dengan sebagian kotiledon berwarna putih tapi tidak pada bagian yang menghubungkan dengan poros embrio. Pola 5 ialah benih berwarna merah terang dengan ujung radikula berwarna putih. Pola 6 ialah benih berwarna merah terang dengan plumula berwarna putih. Pola 7 ialah benih berwarna meah terang dengan sebagain radikula dan sebagian kotiledon berwarna putih. Pola 8 ialah benih berwarna merah muda. Pola 9 ialah benih berwarna putih atau tidak berwarna.

Pola yang dibuat dikelompokan berdasarkan bagian peralihan antara radikula dan kotiledon, ujung radikula, serta persentase bagian yang hidup dari kotiledon, yaitu benih hidup (pola $1-7$ ), benih mati (pola $8-9$ ), kecambah normal kuat (pola $1-2$ ), kecambah normal (pola $1-4$ ), dan kecambah abnormal (pola 5 - 7). Pola untuk benih hidup ialah pola $1-7$, sedangkan pola untuk benih mati ialah pola $8-9$. Pola untuk kecambah normal kuat ialah pola $1-2$, pola untuk kecambah normal ialah pola $1-4$, sedangkan pola untuk kecambah abnormal ialah pola $5-7$.

\section{Lot Benih A}

Pengusangan cepat secara fisik lot benih A berpengaruh secara nyata terhadap tolok ukur kecambah normal, tapi tidak berpengaruh secara nyata terhadap tolok ukur benih hidup dan kecambah normal kuat. Hasil pengujian tetrazolium lima sub lot benih A menunjukkan nilai benih hidup berkisar $98-100 \%$, nilai kecambah normal berkisar $33.33-56 \%$, dan nilai kecambah normal kuat berkisar 18.67 - 30.67\% (Tabel 2). Menurut Muis et al. (2004), semakin lama waktu pengusangan maka pola warna merah pada pengujian tetrazolium benih kayu kuku (Pericopsis mooniana) juga semakin menurun.

Tolok ukur PTM, DB, dan $\mathrm{K}_{\mathrm{ST}}$ pada lot benih A tidak dipengaruhi secara nyata oleh pengusangan cepat secara fisik. Hasil pengujian langsung lima lot benih $\mathrm{A}$ menunjukkan nilai PTM berkisar antara 93.33-98.67\%, nilai DB berkisar antara $73.33-90.67 \%$, dan nilai $\mathrm{K}_{\mathrm{ST}}$ berkisar antara 36-64\% (Tabel 2).

Tabel 2. Hasil pengujian tetrazolium dan pengujian langsung pada lima sub lot benih A

\begin{tabular}{lllllll}
\hline & \multicolumn{3}{c}{ Pengujian Tetrazolium } & \multicolumn{3}{c}{ Pengujian Langsung } \\
\cline { 2 - 7 } Sub Lot Benih & $\begin{array}{l}\text { Benih Hidup } \\
(\%)\end{array}$ & $\begin{array}{l}\text { Kecambah } \\
\text { Normal } \\
(\%)\end{array}$ & $\begin{array}{l}\text { Kecambah } \\
\text { Normal Kuat } \\
(\%)\end{array}$ & PTM $(\%)$ & DB $(\%)$ & $\mathrm{K}_{\mathrm{ST}}(\%)$ \\
\hline A1 & 98.67 & $56.00 \mathrm{a}$ & 30.67 & 96.00 & 90.67 & 61.33 \\
A2 & 100.00 & $46.67 \mathrm{ab}$ & 30.00 & 93.33 & 81.33 & 64.00 \\
A3 & 100.00 & $38.67 \mathrm{~b}$ & 28.00 & 98.67 & 73.33 & 44.00 \\
A4 & 100.00 & $33.33 \mathrm{~b}$ & 18.67 & 93.33 & 78.67 & 36.00 \\
A5 & 98.67 & $36.00 \mathrm{~b}$ & 24.00 & 98.67 & 85.33 & 50.67 \\
\hline
\end{tabular}

Pengusangan 0 jam (A1), 8 jam (A2), 12 jam (A3); 16 jam (A4), 20 jam (A5); PTM : potensi tumbuh maksimum; DB : daya berkecambah; $\mathrm{K}_{\mathrm{ST}}$ : keserempakan tumbuh; Angka-angka pada kolom yang sama yang diikuti oleh huruf yang sama tidak berbeda nyata pada taraf uji $5 \%$ (uji selang berganda Duncan)

Korelasi antara tolok ukur kecambah normal dan DB serta korelasi antara tolok ukur kecambah normal kuat dan KST pada lot benih A memiliki arah yang positif atau searah, sedangkan korelasi antara tolok ukur benih hidup dan PTM memiliki arah yang negatif atau berlawanan arah (Tabel 3). Pola pewarnaan tetrazolium yang dibuat kurang sensitif dalam mendeteksi benih hidup pada lot benih A. Kisaran pola 1 - 7 diduga terlalu longgar untuk dikelompokkan sebagai benih hidup. Pola 7 yang merupakan pola benih 
yang berpotensi menjadi kecambah abnormal dengan ciri-ciri sebagian radikula dan sebagian kotiledon yang berdekatan dengan poros embrio tidak berwarna, pada pengujian langsung mungkin tidak dapat berkecambah abnormal atau termasuk kedalam kelompok benih mati. Menurut Leist (2004), area kotiledon yang berdekatan dengan radikula adalah area penting sehingga tidak terwarnainya daerah ini menunjukkan terjadinya kerusakan yang menyebabkan benih tidak dapat berkecambah.

Nilai koefisien korelasi (r) tidak nyata pada semua tolok ukur. Tetapi, nilai koefisien korelasi antara tolok ukur kecambah normal kuat dengan $\mathrm{K}_{\text {ST }}$ pada lot benih A paling erat, yaitu 0.84 (Tabel 3). Nilai koefisien determinasi $\left(R^{2}\right)$ antara tolok ukur kecambah normal kuat dengan $\mathrm{K}_{\mathrm{ST}}$ mencapai $70.90 \%$ (Tabel 3).

Tabel 3. Analisis korelasi dan regresi antara pengujian tetrazolium dengan pengujian langsung lot benih A

\begin{tabular}{lcccc}
\hline $\begin{array}{c}\text { Tolok Ukur } \\
(\mathrm{y})\end{array}$ & $\begin{array}{c}\text { Tolok Ukur } \\
(\mathrm{x})\end{array}$ & $\begin{array}{c}\text { Koefisien Korelasi } \\
(\mathrm{r})\end{array}$ & $\begin{array}{c}\text { Koefisien Determinasi } \\
\left(\mathrm{R}^{2}\right)\end{array}$ & Persamaan Regresi \\
\hline Benih Hidup & PTM & $-0.46^{\mathrm{tn}}$ & 20.80 & $\mathrm{y}=111.00-0.12 \mathrm{x}$ \\
Kecambah & DB & $0.64^{\mathrm{tn}}$ & 41.50 & $\mathrm{y}=-31.80+0.90 \mathrm{x}$ \\
$\begin{array}{l}\text { Normal } \\
\text { Kecambah }\end{array}$ & $\mathrm{K}_{\mathrm{ST}}$ & $0.84^{\mathrm{tn}}$ & 70.90 & $\mathrm{y}=7.95+0.36 \mathrm{x}$ \\
Normal Kuat & & $0.905)$ &
\end{tabular}

PTM : potensi tumbuh maksimum (\%); DB : daya berkecambah (\%); $\mathrm{K}_{\mathrm{ST}}$ : keserempakan tumbuh (\%); tn : tidak nyata pada taraf uji $5 \%$

\section{Lot Benih B}

Pengusangan cepat secara fisik pada lot benih $\mathrm{B}$ tidak berpengaruh secara nyata terhadap semua tolok ukur pengujian tetrazolium. Hasil pengujian tetrazolium lima sub lot benih B menunjukkan nilai benih hidup yang stagnan $100 \%$, nilai kecambah normal berkisar $92-98 \%$, dan nilai kecambah normal kuat berkisar 61.3390.67\% (Tabel 4).

Tolok ukur PTM, DB, dan $\mathrm{K}_{\mathrm{ST}}$ pada lot benih $\mathrm{B}$ tidak dipengaruhi secara nyata oleh pengusangan cepat secara fisik. Hasil pengujian langsung lima lot benih $\mathrm{B}$ menunjukkan nilai PTM berkisar antara 92-100\%, nilai DB berkisar antara $86.67-96 \%$, dan nilai $\mathrm{K}_{\mathrm{ST}}$ berkisar antara 56-77.33\% (Tabel 4).

Pengusangan cepat secara fisik sampai 20 jam belum cukup menyebabkan keragaman viabilitas lot benih B. Hal ini diduga karena benih koro pedang mempunyai kulit (testa) yang keras sehingga permeabilitasnya rendah. Menurut Ma et al. (2004), permeabilitas kulit benih ditentukan oleh jaringan palisade yang di dalamnya terdapat sebuah lapisan (light line) yang diduga berfungsi sebagai pengatur proses imbibisi ke dalam benih. Krisnawati dan Adie (2008) juga melaporkan bahwa light line pada kulit benih legum yang keras memiliki sifat impermeabilitas yang tinggi.

Tabel 4. Hasil pengujian tetrazolium dan pengujian langsung pada lima sub lot benih B

\begin{tabular}{lcccccc}
\hline & \multicolumn{3}{c}{ Pengujian Tetrazolium } & \multicolumn{3}{c}{ Pengujian Langsung } \\
\cline { 2 - 6 } Sub Lot Benih & $\begin{array}{c}\text { Benih } \\
\text { Hidup } \\
(\%)\end{array}$ & $\begin{array}{c}\text { Kecambah } \\
\text { Normal }\end{array}$ & $\begin{array}{c}\text { Kecambah } \\
\text { Normal Kuat } \\
(\%)\end{array}$ & PTM $(\%)$ & DB $(\%)$ & $\mathrm{K}_{\mathrm{ST}}(\%)$ \\
\hline B1 & 100.00 & 98.67 & 90.67 & 97.33 & 88.00 & 65.33 \\
B2 & 100.00 & 98.67 & 72.00 & 97.33 & 94.67 & 77.33 \\
B3 & 100.00 & 98.67 & 62.67 & 93.33 & 92.00 & 69.33 \\
B4 & 100.00 & 98.67 & 72.00 & 100.00 & 96.00 & 56.00 \\
B5 & 100.00 & 92.00 & 61.33 & 92.00 & 86.67 & 70.67 \\
\hline
\end{tabular}

Pengusangan 0 jam (B1), 8 jam (B2), 12 jam (B3); 16 jam (B4), 20 jam (B5); PTM : potensi tumbuh maksimum; DB : daya berkecambah; $\mathrm{K}_{\mathrm{ST}}$ : keserempakan tumbuh

Korelasi antara tolok ukur kecambah normal dengan DB pada lot benih B memiliki arah yang positif atau searah, sedangkan korelasi antara tolok ukur kecambah normal kuat dengan $\mathrm{K}_{\mathrm{ST}}$ memiliki arah yang negatif atau berlawanan arah (Tabel 5). Pola pewarnaan tetrazolium yang dibuat kurang sensitif dalam mendeteksi kecambah normal kuat pada lot benih B. Kisaran pola 1-2 sebagai pola untuk kecambah normal kuat diduga terlalu longgar. Pola 2 yang merupakan pola benih yang berpotensi menjadi kecambah normal kuat dengan ciri-ciri ada warna merah agak tua pada sebagian kotiledon, pada pengujian langsung mungkin tidak dapat berkecambah normal kuat atau hanya dapat berkecambah normal. Hal ini didukung oleh Leist (2004) yang menyatakan bahwa benih dikotil bervigor tinggi memiliki ciri-ciri yaitu seluruh 
bagian kotiledon terwarnai dengan warna merah yang cerah dan merata.

Nilai koefisien korelasi (r) tidak nyata pada semua tolok ukur. Tetapi, nilai koefisien korelasi antara tolok ukur kecambah normal dengan DB pada lot benih B paling erat, yaitu 0.66 (Tabel 5). Nilai koefisien determinasi $\left(R^{2}\right)$ antara tolok ukur kecambah normal dengan DB hanya mencapai $43.50 \%$ (Tabel 5).

Tabel 5. Analisis korelasi dan regresi antara pengujian tetrazolium dengan pengujian langsung lot benih B

\begin{tabular}{lcccc}
\hline $\begin{array}{c}\text { Tolok Ukur } \\
(\mathrm{y})\end{array}$ & $\begin{array}{c}\text { Tolok Ukur } \\
(\mathrm{x})\end{array}$ & $\begin{array}{c}\text { Koefisien Korelasi } \\
(\mathrm{r})\end{array}$ & Koefisien Determinasi $\left(\mathrm{R}^{2}\right)$ & Persamaan Regresi \\
\hline $\begin{array}{l}\text { Kecambah } \\
\text { Normal }\end{array}$ & $\mathrm{DB}$ & $0.66^{\mathrm{tn}}$ & 43.50 & $\mathrm{y}=53.10+0.48 \mathrm{x}$ \\
$\begin{array}{l}\text { Kecambah } \\
\text { Normal Kuat }\end{array}$ & $\mathrm{K}_{\mathrm{ST}}$ & $-0.25^{\mathrm{tn}}$ & 6.10 & $\mathrm{y}=96.70-0.37 \mathrm{x}$ \\
\hline
\end{tabular}

DB : daya berkecambah (\%); $\mathrm{K}_{\mathrm{ST}}$ : keserempakan tumbuh (\%); tn : tidak nyata pada taraf uji 5\%

\section{Lot Benih C}

Pengusangan cepat secara fisik lot benih C tidak berpengaruh secara nyata terhadap tolok ukur pengujian tetrazolium. Hasil pengujian tetrazolium lima sub lot benih $\mathrm{C}$ menunjukkan nilai benih hidup yang stagnan $100 \%$, nilai kecambah normal berkisar 94.67-100\%, dan nilai kecambah normal kuat berkisar 69.33-68\% (Tabel 8).

Tolok ukur PTM, DB, dan $\mathrm{K}_{\mathrm{ST}}$ pada lot benih $\mathrm{D}$ tidak dipengaruhi secara nyata oleh pengusangan cepat secara fisik. Hasil pengujian langsung lima lot benih $\mathrm{D}$ menunjukkan nilai PTM berkisar 84-100\%, nilai DB berkisar 80-
97.33\%, dan nilai $\mathrm{K}_{\mathrm{ST}}$ berkisar yaitu $64-96 \%$ (Tabel 8).

Nilai kecambah normal kuat cenderung lebih rendah (49.33-68\%) dibandingkan nilai $\mathrm{K}_{\mathrm{ST}}$ yang berkisar $64-96 \%$ (Tabel 8). Hal ini terjadi diduga karena adanya keragaman kondisi fisik pada lot benih C. Menurut Zanzibar dan Herdiana (2010), keragaman kondisi fisik pada lot benih dapat menyebabkan terjadinya keragaman proses reduksi yang dapat menghambat penetrasi garam tetrazolium sehingga pewarnaan menjadi kurang cerah. Oleh karena itu, benih yang berpotensi menjadi kecambah normal kuat pada pengujian tetrazolium menjadi berkurang.

Tabel 8. Hasil pengujian tetrazolium dan pengujian langsung pada lima sub lot benih C

\begin{tabular}{lllllll}
\hline & \multicolumn{3}{c}{ Pengujian Tetrazolium } & \multicolumn{3}{c}{ Pengujian Langsung } \\
\cline { 2 - 7 } Sub Lot Benih & $\begin{array}{l}\text { Benih Hidup } \\
(\%)\end{array}$ & $\begin{array}{l}\text { Kecambah } \\
\text { Normal } \\
(\%)\end{array}$ & $\begin{array}{l}\text { Kecambah } \\
\text { Normal Kuat } \\
(\%)\end{array}$ & PTM $(\%)$ & DB (\%) & $\mathrm{K}_{\mathrm{ST}}(\%)$ \\
\hline C1 & 100.00 & 100.00 & 68.00 & 98.67 & 97.33 & 76.00 \\
C2 & 100.00 & 98.67 & 61.33 & 100.00 & 97.33 & 96.00 \\
C3 & 100.00 & 94.67 & 54.67 & 100.00 & 93.33 & 80.00 \\
C4 & 100.00 & 94.67 & 53.33 & 97.33 & 97.33 & 77.33 \\
C5 & 100.00 & 98.67 & 49.33 & 84.00 & 80.00 & 64.00 \\
\hline
\end{tabular}

Pengusangan 0 jam (C1), 8 jam (C2), 12 jam (C3); 16 jam (C4), 20 jam (C5); PTM : potensi tumbuh maksimum; DB : daya berkecambah; $\mathrm{K}_{\mathrm{ST}}$ : keserempakan tumbuh

Korelasi antara tolok ukur kecambah normal kuat dan $\mathrm{K}_{\mathrm{ST}}$ pada lot benih $\mathrm{C}$ memiliki arah yang positif atau searah, sedangkan korelasi antara tolok ukur kecambah normal dan DB memiliki arah yang negatif atau berlawanan arah (Tabel 9). Pola pewarnaan tetrazolium yang dibuat kurang sensitif dalam mendeteksi kecambah normal pada lot benih C. Kisaran pola 1 - 4 sebagai pola untuk kecambah normal diduga terlalu longgar. Pola 4 yang merupakan pola benih yang berpotensi menjadi kecambah normal dengan ciri-ciri ada bagian kotiledonnya (tidak pada bagian yang menghubungkan dengan poros embrio) yang tidak terwarnai, pada pengujian langsung mungkin termasuk kecambah abnormal. Menurut Leist (2004), bagian kotiledon yang tidak terwarnai menunjukkan kerusakan akibat serangan hama atau penyakit sehingga tidak dapat berkecambah normal.

Nilai koefisien korelasi (r) tidak nyata pada semua tolok ukur. Tetapi, nilai koefisien korelasi antara tolok ukur kecambah normal kuat dengan $\mathrm{K}_{\mathrm{ST}}$ pada lot benih $\mathrm{C}$ paling erat, yaitu 0.47 (Tabel 9). Nilai koefisien determinasi $\left(\mathrm{R}^{2}\right)$ antara tolok ukur $\mathrm{K}_{\text {ST.TTZ }}$ dengan $\mathrm{K}_{\mathrm{ST}}$ hanya mencapai $22.40 \%$ (Tabel 9). 
Tabel 9. Analisis korelasi dan regresi antara pengujian tetrazolium dengan pengujian langsung lot benih $\mathrm{C}$

\begin{tabular}{lcccc}
\hline $\begin{array}{c}\text { Tolok Ukur } \\
(\mathrm{y})\end{array}$ & $\begin{array}{c}\text { Tolok Ukur } \\
(\mathrm{x})\end{array}$ & $\begin{array}{c}\text { Koefisien Korelasi } \\
(\mathrm{r})\end{array}$ & Koefisien Determinasi $\left(\mathrm{R}^{2}\right)$ & Persamaan Regresi \\
\hline $\begin{array}{l}\text { Kecambah } \\
\text { Normal }\end{array}$ & $\mathrm{DB}$ & $-0.17^{\mathrm{tn}}$ & 2.80 & $\mathrm{y}=102.00-0.05 \mathrm{x}$ \\
Kecambah & $\mathrm{K}_{\mathrm{ST}}$ & $0.47^{\mathrm{tn}}$ & 22.40 & $\mathrm{y}=33.40+0.30 \mathrm{x}$ \\
\hline Normal Kuat & &
\end{tabular}

DB : daya berkecambah (\%); $\mathrm{K}_{\mathrm{ST}}$ : keserempakan tumbuh (\%); tn : tidak nyata pada taraf uji 5\%.

\section{Percobaan 2 : Pengujian Respirasi Benih Koro} Pedang

\section{Lot Benih A}

Pengusangan cepat secara fisik lot benih A tidak berpengaruh secara nyata terhadap tolok ukur laju respirasi benih. Hasil pengujian respirasi lima sub lot benih A menunjukkan nilai laju respirasi benih yang berkisar antara 8.72-10.55 $\mathrm{mg} \mathrm{CO}_{2} \mathrm{~kg}$ benih $^{-1} \mathrm{jam}^{-1}$ (Tabel 10).
Tolok ukur PTM, DB, IV, $\mathrm{K}_{\mathrm{ST}}$, dan $\mathrm{K}_{\mathrm{CT}}$ pada lot benih A tidak dipengaruhi secara nyata oleh pengusangan cepat secara fisik. Hasil pengujian langsung lima lot benih A menunjukkan nilai PTM berkisar antara 93.33-98.67\%, nilai DB berkisar antara $73.33-90.67 \%$, nilai IV berkisar antara 33.33-37.33\%, nilai $\mathrm{K}_{\mathrm{ST}}$ berkisar antara 36$64 \%$, dan nilai $\mathrm{K}_{\mathrm{CT}}$ berkisar antara $13.18-15.71 \%$ (Tabel 10).

Tabel 10. Hasil pengujian respirasi dan pengujian langsung pada lima sub lot benih A

\begin{tabular}{lllllll}
\hline \multirow{2}{*}{ Sub Lot Benih } & Pengujian Respirasi & \multicolumn{4}{c}{ Pengujian Langsung } \\
\cline { 2 - 6 } & Laju Respirasi Benih & PTM & DB & IV & $\mathrm{K}_{\text {ST }}$ & $\mathrm{K}_{\mathrm{CT}}$ \\
\hline A1 & 9.09 & 96.00 & 90.67 & 36.00 & 61.33 & 15.71 \\
A2 & 10.12 & 93.33 & 81.33 & 36.00 & 64.00 & 14.34 \\
A3 & 9.74 & 98.67 & 73.33 & 37.33 & 44.00 & 13.18 \\
A4 & 8.72 & 93.33 & 78.67 & 33.33 & 36.00 & 13.59 \\
A5 & 10.55 & 98.67 & 85.33 & 34.67 & 50.67 & 14.99 \\
\hline
\end{tabular}

Pengusangan 0 jam (A1), 8 jam (A2), 12 jam (A3); 16 jam (A4), 20 jam (A5); Laju respirasi benih (mg $\mathrm{CO}_{2} \mathrm{~kg} \mathrm{benih}^{-1}$ jam $^{-1}$ ); PTM : potensi tumbuh maksimum (\%); DB : daya berkecambah (\%); IV : indeks vigor $(\%)$; $\mathrm{K}_{\mathrm{ST}}$ : keserempakan tumbuh $(\%)$; $\mathrm{K}_{\mathrm{CT}}$ : kecepatan tumbuh $\left(\%\right.$ etmal $\left.^{-1}\right)$

Korelasi antara laju respirasi benih dengan PTM, DB, IV, $\mathrm{K}_{\mathrm{ST}}$, dan $\mathrm{K}_{\mathrm{CT}}$ pada lot benih A memiliki arah yang positif atau searah (Tabel 11). Hal ini sesuai dengan Nurfarida (2011) yang melaporkan bahwa korelasi antara laju respirasi benih dengan tolok ukur PTM, DB, IV, $\mathrm{K}_{\mathrm{ST}}$, dan $\mathrm{K}_{\mathrm{CT}}$ pada benih jagung memiliki hubungan yang searah.
Nilai koefisien korelasi (r) tidak nyata pada semua tolok ukur. Tetapi, nilai koefisien korelasi antara laju respirasi benih dengan PTM pada lot benih A paling erat, yaitu 0.49 (Tabel 11). Nilai koefisien determinasi $\left(\mathrm{R}^{2}\right)$ antara laju respirasi benih dengan PTM hanya mencapai $23.80 \%$ (Tabel 11).

Tabel 11. Hasil analisis korelasi dan regresi antara pengujian respirasi dengan pengujian langsung pada lot benih A

\begin{tabular}{|c|c|c|c|c|}
\hline $\begin{array}{l}\text { Tolok Ukur } \\
\text { (y) }\end{array}$ & $\begin{array}{l}\text { Tolok Ukur } \\
\text { (x) }\end{array}$ & $\begin{array}{l}\text { Koefisien Korelasi } \\
\text { (r) }\end{array}$ & $\begin{array}{ll}\begin{array}{l}\text { Koefisien } \\
\left(\mathrm{R}^{2}\right)\end{array} & \text { Determinasi } \\
\end{array}$ & Persamaan Regresi \\
\hline & PTM & $0.49^{\mathrm{tn}}$ & 23.80 & $y=-3.40+0.14 x$ \\
\hline Laju & DB & $0.01^{\text {tn }}$ & 0.00 & $y=9.54+0.001 x$ \\
\hline Respirasi & IV & $0.31^{\mathrm{tn}}$ & 9.40 & $y=4.33+0.15 x$ \\
\hline Benih & $\mathrm{K}_{\mathrm{ST}}$ & $0.38^{\operatorname{tn}}$ & 14.80 & $y=8.40+0.02 x$ \\
\hline & $\mathrm{K}_{\mathrm{CT}}$ & $0.14^{\mathrm{tn}}$ & 2.00 & $\mathrm{y}=8.17+0.10 \mathrm{x}$ \\
\hline
\end{tabular}

Laju respirasi benih (mg CO $\mathrm{kg}_{2}$ benhih $\left.^{-1} \mathrm{jam}^{-1}\right)$; PTM : potensi tumbuh maksimum (\%); DB : daya berkecambah (\%); IV : indeks vigor (\%); $\mathrm{K}_{\mathrm{ST}}$ : keserempakan tumbuh (\%); $\mathrm{K}_{\mathrm{CT}}$ : kecepatan tumbuh (\% etmal $\left.{ }^{-1}\right)$; tn : tidak nyata pada taraf uji $5 \%$

\section{Lot Benih B}

Pengusangan cepat secara fisik lot benih B berpengaruh secara nyata terhadap tolok ukur laju respirasi benih. Hasil pengujian respirasi lima sub lot benih $\mathrm{B}$ menunjukkan nilai laju respirasi benih yang berkisar antara 8.44-12.96 mg $\mathrm{CO}_{2} \mathrm{~kg}$ benih $^{-1}$ jam $^{-1}$ (Tabel 12).

Tolok ukur PTM, DB, IV, $\mathrm{K}_{\mathrm{ST}}$, dan $\mathrm{K}_{\mathrm{CT}}$ pada lot benih $\mathrm{B}$ tidak dipengaruhi secara nyata 
oleh pengusangan cepat secara fisik. Hasil pengujian langsung lima lot benih $\mathrm{B}$ menunjukkan nilai PTM berkisar antara 92-100\%, nilai DB berkisar antara $86.67-96 \%$, nilai IV berkisar antara 37.33-49.33\%, nilai $\mathrm{K}_{\mathrm{ST}}$ berkisar antara 56$77.33 \%$, dan nilai $\mathrm{K}_{\mathrm{CT}}$ berkisar antara 15.40$17.39 \%$ (Tabel 12).

Tabel 12. Hasil pengujian respirasi dan pengujian langsung pada lima sub lot benih B

\begin{tabular}{lcccccc}
\hline \multirow{2}{*}{ Sub Lot Benih } & Pengujian Respirasi & \multicolumn{3}{c}{ Pengujian Langsung } \\
\cline { 2 - 7 } & Laju Respirasi Benih & PTM & DB & IV & $\mathrm{K}_{\mathrm{ST}}$ & $\mathrm{K}_{\mathrm{CT}}$ \\
\hline B1 & $12.96 \mathrm{a}$ & 97.33 & 88.00 & 49.33 & 65.33 & 16.06 \\
B2 & $11.99 \mathrm{ab}$ & 97.33 & 94.67 & 46.67 & 77.33 & 17.21 \\
B3 & $8.44 \mathrm{c}$ & 93.33 & 92.00 & 49.33 & 69.33 & 16.69 \\
B4 & $9.12 \mathrm{c}$ & 100.00 & 96.00 & 46.67 & 56.00 & 17.39 \\
B5 & $9.91 \mathrm{bc}$ & 92.00 & 86.67 & 37.33 & 70.67 & 15.40 \\
\hline
\end{tabular}

Pengusangan 0 jam (B1), 8 jam (B2), 12 jam (B3); 16 jam (B4), 20 jam (B5); Laju respirasi (mg $\mathrm{CO}_{2} \mathrm{~kg} \mathrm{benih}^{-1}$ jam $\left.^{-1}\right) ; \mathrm{PTM}^{2}$ potensi tumbuh maksimum (\%); DB : daya berkecambah (\%); IV : indeks vigor $(\%) ; \mathrm{K}_{\mathrm{ST}}$ : keserempakan tumbuh $(\%)$; $\mathrm{K}_{\mathrm{CT}}$ : kecepatan tumbuh $\left(\%\right.$ etmal $\left.^{-1}\right)$; Angka-angka pada kolom yang sama yang diikuti oleh huruf yang sama tidak berbeda nyata pada taraf uji 5\% (uji selang berganda Duncan)

Korelasi yang positif atau searah pada lot benih B hanya terjadi antara laju respirasi dengan tolok ukur PTM, IV, dan $\mathrm{K}_{\mathrm{ST}}$ (Tabel 13). Hal ini sesuai dengan Baharizki (2012) yang melaporkan bahwa korelasi antara laju respirasi benih dengan tolok ukur PTM, IV, dan $\mathrm{K}_{\mathrm{ST}}$ pada benih kacang tanah juga memiliki hubungan yang searah.
Nilai koefisien korelasi (r) tidak nyata pada semua tolok ukur. Tetapi, nilai koefisien korelasi antara laju respirasi benih dengan $\mathrm{K}_{\mathrm{ST}}$ pada lot benih B paling erat, yaitu 0.32 (Tabel 13). Nilai koefisien determinasi $\left(\mathrm{R}^{2}\right)$ antara laju respirasi benih dengan $\mathrm{K}_{\mathrm{ST}}$ hanya mencapai $10.50 \%$ (Tabel 13).

Tabel 13. Hasil analisis korelasi dan regresi antara pengujian respirasi dengan pengujian langsung pada lot benih B

\begin{tabular}{|c|c|c|c|c|}
\hline $\begin{array}{l}\text { Tolok Ukur } \\
\text { (y) }\end{array}$ & $\begin{array}{l}\text { Tolok Ukur } \\
(\mathrm{x})\end{array}$ & $\begin{array}{l}\text { Koefisien Korelasi } \\
\text { (r) }\end{array}$ & $\begin{array}{l}\text { Koefisien Determinasi } \\
\left(\mathrm{R}^{2}\right)\end{array}$ & Persamaan Regresi \\
\hline & PTM & $0.30^{\operatorname{tn}}$ & 9.20 & $y=-6.60+0.18 x$ \\
\hline Laju & DB & $-0.26^{\mathrm{tn}}$ & 7.00 & $y=21.90-0.12 x$ \\
\hline Respirasi & IV & $0.17^{\mathrm{tn}}$ & 2.90 & $y=7.40+0.07 x$ \\
\hline \multirow[t]{2}{*}{ Benih } & $\mathrm{K}_{\mathrm{ST}}$ & $0.32^{\text {tn }}$ & 10.50 & $y=5.13+0.08 x$ \\
\hline & $\mathrm{K}_{\mathrm{CT}}$ & $-0.16^{\mathrm{tn}}$ & 2.60 & $y=16.70-0.37 x$ \\
\hline
\end{tabular}

Laju respirasi benih $\left(\mathrm{mg} \mathrm{CO}_{2} \mathrm{~kg}_{\text {benih }}{ }^{-1}\right.$ jam $\left.^{-1}\right)$; PTM : potensi tumbuh maksimum (\%); DB : daya berkecambah (\%); IV : indeks vigor $(\%) ; \mathrm{K}_{\mathrm{ST}}$ : keserempakan tumbuh $(\%) ; \mathrm{K}_{\mathrm{CT}}$ : kecepatan tumbuh $\left(\% \mathrm{etmal}^{-1}\right)$; tn : tidak nyata pada taraf uji $5 \%$

\section{Lot Benih C}

Pengusangan cepat secara fisik lot benih C tidak berpengaruh secara nyata terhadap tolok ukur laju respirasi benih. Hasil pengujian respirasi lima sub lot benih $\mathrm{C}$ menunjukkan nilai laju respirasi benih yang cukup rendah yaitu berkisar antara 5.26-8.80 mg CO $2 \mathrm{~kg}_{\text {benih }}{ }^{-1} \mathrm{jam}^{-1}$ (Tabel 16).

Tabel 16. Hasil pengujian respirasi dan pengujian langsung pada lima sub lot benih C

\begin{tabular}{lcccccc}
\hline \multirow{2}{*}{ Sub Lot Benih } & Pengujian Respirasi & \multicolumn{4}{c}{ Pengujian Langsung } \\
\cline { 2 - 7 } & Laju Respirasi & PTM & DB & IV & $\mathrm{K}_{\mathrm{ST}}$ & $\mathrm{K}_{\mathrm{CT}}$ \\
\hline C1 & 8.62 & 98.67 & 97.33 & 60.00 & 76.00 & 17.71 \\
C2 & 8.80 & 100.00 & 97.33 & 64.00 & 96.00 & 18.36 \\
C3 & 7.47 & 100.00 & 93.33 & 48.00 & 80.00 & 17.03 \\
C4 & 8.23 & 97.33 & 97.33 & 41.33 & 77.33 & 17.19 \\
C5 & 5.26 & 84.00 & 80.00 & 33.33 & 64.00 & 14.09 \\
\hline
\end{tabular}

Pengusangan 0 jam (C1), 8 jam (C2), 12 jam (C3); 16 jam (C4), 20 jam (C5); Laju respirasi (mg $\mathrm{CO}_{2} \mathrm{~kg}_{\text {benih }}^{-1}$ jam $\left.^{-1}\right)$; PTM : potensi tumbuh maksimum (\%); DB : daya berkecambah (\%); IV : indeks vigor $(\%)$; $\mathrm{K}_{\mathrm{ST}}$ : keserempakan tumbuh $(\%)$; $\mathrm{K}_{\mathrm{CT}}$ : kecepatan tumbuh $\left(\%\right.$ etmal $\left.^{-1}\right)$

Tolok ukur PTM, DB, IV, $\mathrm{K}_{\mathrm{ST}}$, dan $\mathrm{K}_{\mathrm{CT}}$ pada lot benih $\mathrm{C}$ tidak dipengaruhi secara nyata oleh pengusangan cepat secara fisik. Hasil pengujian langsung lima lot benih $\mathrm{C}$ menunjukkan nilai PTM berkisar antara 84-100\%, nilai DB berkisar antara $80-97.33 \%$, nilai IV berkisar antara 33.33-64\%, nilai $\mathrm{K}_{\mathrm{ST}}$ berkisar antara 64$96 \%$, dan nilai $\mathrm{K}_{\mathrm{CT}}$ berkisar antara $14.09-18.36 \%$ 
(Tabel 16). Lot benih $\mathrm{C}$ memiliki nilai laju respirasi yang cukup rendah. Hal ini sesuai dengan vigor benihnya yang sudah rendah, dengan nilai IV yang hanya mencapai 64\% (Tabel 16). Menurut Shintarika et al. (2013), benih memiliki vigor yang tinggi apabila setelah diusangkan masih memiliki IV yang tinggi.

Korelasi antara laju respirasi benih dengan PTM, DB, IV, $\mathrm{K}_{\mathrm{ST}}$, dan $\mathrm{K}_{\mathrm{CT}}$ pada lot benih $\mathrm{C}$ memiliki arah yang positif atau searah (Tabel 17). Hal ini sesuai dengan Permatasari (2011) yang melaporkan bahwa korelasi antara laju respirasi benih dengan tolok ukur PTM, DB, IV,
$\mathrm{K}_{\mathrm{ST}}$, dan $\mathrm{K}_{\mathrm{CT}}$ pada benih kedelai memiliki hubungan yang searah.

Nilai koefisien korelasi (r) sangat nyata pada korelasi antara laju respirasi dengan $\mathrm{K}_{\mathrm{CT}}$, nyata pada korelasi antara laju respirasi dengan DB, dan tidak nyata pada korelasi antara laju respirasi dengan PTM, IV, dan $\mathrm{K}_{\mathrm{ST}}$ (Tabel 17). Nilai koefisien korelasi antara laju respirasi benih dengan $\mathrm{K}_{\mathrm{CT}}$ paling erat, yaitu 0.96 (Tabel 17). Nilai koefisien determinasi $\left(\mathrm{R}^{2}\right)$ antara laju respirasi dengan tolok ukur $\mathrm{K}_{\mathrm{CT}}$ juga paling tinggi, yaitu mencapai $92.30 \%$ (Tabel 17).

Tabel 17. Hasil analisis korelasi dan regresi antara pengujian respirasi dengan pengujian langsung pada lot benih $\mathrm{C}$

\begin{tabular}{lcccc}
\hline $\begin{array}{c}\text { Tolok Ukur } \\
(\mathrm{y})\end{array}$ & $\begin{array}{c}\text { Tolok Ukur } \\
(\mathrm{x})\end{array}$ & $\begin{array}{c}\text { Koefisien Korelasi } \\
(\mathrm{r})\end{array}$ & $\begin{array}{c}\text { Koefisien Determinasi } \\
\left(\mathrm{R}^{2}\right)\end{array}$ & Persamaan Regresi \\
\hline & PTM & $0.85^{\text {th }}$ & 71.90 & $\mathrm{y}=-4.58+0.13 \mathrm{x}$ \\
Laju & $\mathrm{DB}$ & $0.95^{*}$ & 90.40 & $\mathrm{y}=-4.39+0.13 \mathrm{x}$ \\
Respirasi & $\mathrm{IV}$ & $0.85^{\text {tn }}$ & 72.50 & $\mathrm{y}=4.45+0.07 \mathrm{x}$ \\
Benih & $\mathrm{K}_{\mathrm{ST}}$ & $0.77^{\text {tn }}$ & 59.50 & $\mathrm{y}=2.37+0.07 \mathrm{x}$ \\
& $\mathrm{K}_{\mathrm{CT}}$ & $0.96^{* *}$ & 92.30 & $\mathrm{y}=-2.41+0.61 \mathrm{x}$ \\
\hline
\end{tabular}

Laju respirasi benih $\left(\mathrm{mg} \mathrm{CO}_{2} \mathrm{~kg}\right.$ benih $^{-1}$ jam $\left.^{-1}\right)$; PTM : potensi tumbuh maksimum (\%); DB : daya berkecambah (\%); IV : indeks vigor $(\%) ; \mathrm{K}_{\mathrm{ST}}$ : keserempakan tumbuh $(\%) ; \mathrm{K}_{\mathrm{CT}}$ : kecepatan tumbuh $\left(\%\right.$ etmal $\left.^{-1}\right)$; **: sangat nyata, * : nyata, tn : tidak nyata pada taraf uji $5 \%$

\section{KESIMPULAN}

Hasil pembuatan sub lot benih dengan waterbath belum bisa menghasilkan mutu fisiologis benih koro pedang yang gradual. Pola topografi pewarnaan tetrazolium benih koro pedang yang dibuat dalam penelitian ini belum bisa digunakan untuk mengevaluasi mutu fisiologis benih koro pedang karena polanya kurang bervariasi. Metode pengujian respirasi benih dengan cosmotector belum bisa digunakan untuk mengevaluasi mutu fisiologis benih koro pedang karena alat yang digunakan untuk pengukuran laju respirasi benih masih belum sempurna sehingga diperkirakan ada $\mathrm{CO}_{2}$ yang terbuang dan tidak terukur.

\section{DAFTAR PUSTAKA}

Babiker, A. Z., Dullo, M. E., El Balla, M. A. M., Ibrahim, E. T. 2010. Effect low cost drying methods on seed quality of Sorghum bicolor (L.) Moench. Afr. J. Plant. Sci 4:339:345.

Baharizki, J. 2012. Pengembangan uji cepat viabilitas dan vigor benih kacang tanah (Arachis hypogaea L.) menggunakan

pengukuran respirasi dengan alat kosmotektor. [Skripsi]. Bogor (ID): Institut Pertanian Bogor.
[Distan] Dinas Pertanian dan Ketahanan Pangan Provinsi Gorontalo. 2013. Teknis Perbanyakan Benih Tanaman Padi, Jagung, dan Kedelai. Tersedia pada : http://distan.gorontaloprov.go.id [diunduh 2 Desember 2014].

Doss, A., Pugalenthi, M., Vadivel, V. G., Subhashini, G., Subash, R. A. 2011. Effects of processing technique on the nutritional composition and antinutrients content of under utilized food legume Canavalia ensiformis L.DC. Int Food Res $J$ 18(3): 965-970.

[ISTA] International Seed Testing Association (ZH). 2014. Seed Science and Technology. International Rules for Seed Testing.

Krisnawati, A., Edie, M. M. 2008. Ragam karakter morfologi kulit biji beberapa genotipe plasma nutfah kedelai. Bul. Plasm Nutf 14(1):14-18.

Febriyanti, F. 2013. Viabilitas benih koro pedang putih (Canavalia ensiformis (L.)DC) yang disimpan pada beberapa jenis kemasan dan periode simpan. [Skripsi]. Bogor (ID): Institut Pertanian Bogor. 
Leist, N. 2004. Seed vigour determination by means of the topographical tetrazolium test. Makalah dalam ISTA Seed Quality

Ma, F., Cholewa, E., Mohamed, T., Peterson, C. A., Gijzen, M. 2004. Cracks in the palisade cuticle of soybean seed with their permeability to water [internet]. Ann Bot. [diunduh : 2014 Des 2]. Tersedia pada : http://aob.oxfordjournals.org.

Nurfarida, M. 2011. Pengembangan uji cepat vigor benih jagung (Zea mays L.) dengan alat pengukur laju respirasi kosmotektor. [Skripsi]. Bogor (ID): Institut Pertanian Bogor.

Muis, M. I., Satjapradja, O., Luluk, S., Zanzibar. 2004. Penentuan viabilitas benih kayu kuku (Pericopsis mooniana) berdasarkan uji cepat (uji tetrazolium, uji eksisi embrio, uji belah, dan uji hidrogen peroksida). J Nus Syl 4:9-24.

Permatasari, O. S. I. 2011. Pengembangan uji cepat vigor benih kedelai (Glycine max L.
Assesment Training. Dilaksanakan pada : 2004 November 22-26. Hanoi (VN) : APSA

Merr.)menggunakan metode respirasi dengan alat kosmotektor. [Skripsi]. Bogor (ID): Institut Pertanian Bogor.

[Puslitbangtan] Pusat Penelitian dan Pengembangan Tanaman Pangan (ID). 2007. Kelayakan dan teknologi budi daya koro pedang (Canavalia sp). Tersedia pada : www.puslittan.bogor.net. [diunduh 10 Okt0ber 2014].

Sadjad, S. 1993. Dari Benih Kepada Benih. Jakarta (ID): Penerbit Grasindo.

Shintarika, F., Suwarno, F. C., Suwarno. 2013. Pengujian vigor daya simpan dan vigor terhadap kekeringan pada benih padi gogo dan padi sawah. Bul. Agrohort 1:67-61.

Zanzibar, M., Herdiana, N. 2010. Akurasi metode uji cepat dalam menduga mutu fisiologis benih damar. J. Penelit Hut Tan 7(4):181189. 